\title{
SISTEM KEPUTUSAN METODE SAW DAN TOPSIS UNTUK PEMILIHAN STAFF PEDULI LAKA STUDI KASUS: PT EXPRESS POOL CIPAYUNG
}

\author{
Nuzuliarini Nuris \\ Manajemen Informatika. AMIK BSI Jakarta \\ nuzuliarini.nzn@bsi.ac.id
}

\begin{abstract}
Decision Making System is a system which assists problems to make accurate and correct decisions. Many problems can be solved by using the decision support system. This research was conducted to selection of staff laka care with SAW and TOPSIS, where this method widely used because of a method of the simple concept, easily understood, computerized his efficient and have the ability to measure the performance of alternatives decision in the form of simple mathematical. The problem is of the two method, then which method is going to have value more relevant. Because it was done by comparison test of the reliability of the two method. Moved closer to the value of 1 to test his reliability of course this method will be more recommended to help the decision-making process. Testing methods which has been the result of saw and topsis namely 0,9564 and 0,9770.
\end{abstract}

\section{Keywords: Decision Making System, SAW and TOPSIS.}

Abstrak - Sistem penunjang keputusan adalah sistem yang dapat membantu permasalahan dalam mengambil keputusan yang akurat dan tepat sasaran. Banyak permasalahan yang dapat diselesaikan dengan menggunakan sistem pengambilan keputusan. Penelitian ini dilakukan untuk pemilihan staf peduli laka dengan menggunakan Metode SAW dan TOPSIS dimana metode ini banyak digunakan dikarenakan metode tersebut konsepnya sederhana, mudah dipahami, komputasinya efisien dan memiliki kemampuan untuk mengukur kinerja dari alternatif-alternatif keputusan dalam bentuk matematis yang sederhana. Permasalahannya adalah dari kedua metode tersebut, metode mana yang akan memiliki nilai lebih relevan. Oleh karena itu dilakukan perbandingan hasil uji reliabilitas terhadap hasil dari kedua metode tersebut. Semakin mendekati nilai 1 untuk hasil uji reliabilitasnya tentunya metode tersebut akan semakin direkomendasikan untuk membantu pengambilan keputusan. Pengujian metode yang dilakukan menunjukkan hasil dari metode SAW dan TOPSIS yaitu 0,9564 dan 0,9770

\section{Kata Kunci: Sistem Penunjang Keputusan, SAW dan TOPSIS}

\section{A. PEndahuluan}

Peduli laka didefinisikan sebagai sebuah organisasi yang dibentuk oleh mitra PT Express secara sukarela atas dasar kesamaan kegiatan profesi dan fungsi serta berperan dalam penanganan kecelakaan kesehatan khusus untuk pengemudi namun dengan ketentuan dari perusahaan. Untuk mendapatkan staf peduli laka yang sesuai dengan prinsip peduli laka seperti yang tertuang dalam buku panduannya diperlukan penyeleksian dalam pemilihan seorang staf peduli laka yang berjiwa sosial, loyalitas tinggi serta dapat membawahi semua pengemudi. Pemilihan staf peduli laka adalah salah satu kegiatan yang penting untuk kelangsungan hubungan mitra dengan PT Express. Maka perlu diselenggarakannya pemilihan staf peduli laka tersebut dengan tahapan-tahapan yang rumit dan butuh waktu yang cukup lama untuk melakukan setiap proses pemilihan itu sendiri. Dalam hal ini memilih staf peduli laka harus ditentukan oleh orang-orang yang berkepentingan dalam pengambilan keputusan tersebut.
Ada banyak metode yang bisa digunakan dalam membantu menunjang keputusan. Multi Attribute Decision Making merupakan salah satu metode penunjang pengambilan keputusan yang cukup sederhana dan dapat menjadi salah satu alternatif dalam mengambil keputusan jika alternative atau attribute yang digunakan cukup banyak dan bernilai data kuantitatif. Multi Attribute Decision Making sendiri memiliki beberapa metode didalamnya yang dapat membantu memberikan alternatif terbaik diantaranya: Simple Additive Weighting (SAW), Technique for Order Preference by Similarity to Ideal Solution (TOPSIS) dan Weighted Product Method (WPM).

Pada prosesnya Multi Attribute Decision Making melakukan beberapa hal, diantaranya: menentukan prioritas dari setiap kriteria, melakukan pembuatan matriks nominasi, melakukan proses perhitungan berdasarkan masing-masing metode, melakukan pembobotan sampai dengan membuat ranking keputusan. Metode SAW dan TOPSIS merupakan yang paling banyak digunakan karena metode tersebut konsepnya sederhana, 
mudah dipahami, komputasinya efisien dan memiliki kemampuan untuk mengukur kinerja dari alternatif-alternatif keputusan dalam bentuk matematis yang sederhana.

\section{B. LANDASAN TEORI}

Sistem pendukung keputusan ialah proses pengambilan keputusan dengan bantuan media komputer dalam proses pengambil keputusan dengan menggunakan beberapa data dan model tertentu untuk menyelesaikan beberapa masalah yang tidak terstruktur.

Menurut Turban dan Aronson (2011: 75), "Sistem Pendukung Keputusan (SPK) adalah sistem yang dimaksudkan untuk mendukung pembuat keputusan manajerial dalam situasi keputusan semiterstruktur dan terstruktur"

Ciri-ciri sistem pendukung keputusan atau decision support system (DSS) yang dirumuskan oleh Kusrini (2009) adalah sebagai berikut:

1. Sistem pendukung keputusan atau decision support system (DSS) ditujukan untuk membantu keputusan-keputusan yang kurang terstruktur.

2. Sistem pendukung keputusan atau decision support system (DSS) merupakan gabungan antara kumpulan model kualitatif dan kumpulan data.
3. Sistem pendukung keputusan atau decision support system (DSS) bersifat luwes dan dapat menyesuaikan dengan perubahanperubahan yang terjadi.

Sistem berbasis model yang terdiri dari prosedur-prosedur dalam pemrosesan data dan pertimbangannya untuk membantu manajer dalam mengambil keputusan. Agar berhasil mencapai tujuannya maka sistem tersebut harus:
1. Sederhana
2. Robust
3. Mudah untuk dikontrol
4. Mudah beradaptasi
5. Lengkap pada hal-hal penting
6. Mudah berkomunikasi dengannya.

Secara implisit juga berarti bahwa sistem ini harus berbasis komputer dan digunakan sebagai tambahan dari kemampuan penyelesaian masalah dari seseorang. Langkah-langkah pengambilan keputusan meliputi fase-fase:

1. Intelligence yaitu kegiatan untuk mengenali masalah, kebutuhan atau kesempatan

2. Design yaitu cara-cara untuk memecahkan masalah/memenuhi kebutuhan

3. Choice yaitu memilih alternatif keputusan yang terbaik

4. Implementation yang disertai dengan pengawasan dan koreksi yang diperlukan

Literatur mengenai penggunaan metode SPK banyak ditemukan dalam buku maupun jurnaljurnal ilmiah baik didalam maupun diluar negeri, berikut ini adalah beberapa topik penelitian terdahulu yang terkait.

\begin{tabular}{|c|c|c|c|c|c|}
\hline No. & Peneliti, Judul/Tahun & $\begin{array}{c}\text { Tujuan } \\
\end{array}$ & Metodologi & Hasil & Komentar \\
\hline 1 & $\begin{array}{l}\text { Apriansyah Putra, Dinna Yunika } \\
\text { Hardiyanti, Penentuan Penerima } \\
\text { Beasiswa Dengan } \\
\text { Menggunakan Fuzzy } \\
\text { MADM/2011 }\end{array}$ & $\begin{array}{l}\text { Mempersingkat waktu penyeleksian dan } \\
\text { dapat meningkatkan kualitas keputusan } \\
\text { dalam penentukan penerima beasiswa PPA } \\
\text { dan BBM }\end{array}$ & $\begin{array}{l}\text { Menggunakan metode SAW } \\
\text { untuk membantu } \\
\text { mempersingkat waktu dalam } \\
\text { pemberian BBM \& PPA }\end{array}$ & Pemberian beasiswa & $\begin{array}{l}\text { Logika fuzzy dapat } \\
\text { digunakan pada } \\
\text { pencarian keputusan } \\
\text { pemberian beasiswa }\end{array}$ \\
\hline 2 & $\begin{array}{l}\text { Widayanti Deni, Oka Sudana, } \\
\text { Arya Sasmita, Analisys And } \\
\text { Implementation Fuzzy Multi- } \\
\text { Attribute Decision Making SAW } \\
\text { Method For Selection Of High } \\
\text { Achieving Student In Faculty } \\
\text { Level/2013 }\end{array}$ & $\begin{array}{l}\text { Untuk melakukan analisis sehingga setiap } \\
\text { keputusan proses dibuat berdasarkan } \\
\text { kriteria yang ada menggunakan model } \\
\text { Fuzzy Multi-Attribute Decision Making } \\
\text { (FMADM), Metode Simple Additive } \\
\text { Weighting (SAW). }\end{array}$ & $\begin{array}{l}\text { Pemanfaatan metode SAW } \\
\text { untuk menyeleksis penerimaan } \\
\text { siswa }\end{array}$ & $\begin{array}{l}\text { Penyeleksian penerimaan } \\
\text { siswa }\end{array}$ & $\begin{array}{l}\text { Variable yang dipakai } \\
\text { belum begitu kompleks }\end{array}$ \\
\hline 3 & $\begin{array}{l}\text { Fera Tri Wulandari, } \\
\text { Implementasi Fuzzy TOPSIS } \\
\text { Dalam Perencanaan Strategi } \\
\text { Bisnis/2013 }\end{array}$ & $\begin{array}{l}\text { Menentukan dan memilih strategi terbaik } \\
\text { dari sejumlah alternatif strategi yang } \\
\text { diberikan dengan kriteria tertentu } \\
\text { menggunakan Fuzzy Technique for Order } \\
\text { Preference by Similarity to Ideal Solution } \\
\text { (TOPSIS) }\end{array}$ & $\begin{array}{l}\text { Melakukan pendekatan bisnis } \\
\text { menggunakan metode TOPSIS }\end{array}$ & $\begin{array}{l}\text { Merencanakan strategi } \\
\text { bisnis }\end{array}$ & $\begin{array}{l}\text { TOPSIS dapat } \\
\text { digunakan pada } \\
\text { penerapan } \\
\text { perencanaan strategi } \\
\text { bisnis. }\end{array}$ \\
\hline 4 & $\begin{array}{l}\text { Henry Wibowo S, MADM-Tool: } \\
\text { Aplikasi Uji Sensitivitas Untuk } \\
\text { Model MADM Menggunakan } \\
\text { Metode SAW Dan TOPSIS/2010 }\end{array}$ & $\begin{array}{l}\text { Membantu dalam pengambilan keputusan } \\
\text { yang optimal dan membantu dalam } \\
\text { menentukan metode mana yang lebih baik } \\
\text { antara SAW dan TOPSIS dengan } \\
\text { melakukan uji sensitivitas. }\end{array}$ & $\begin{array}{l}\text { Menghitung prosentase } \\
\text { perubahan ranking dengan cara } \\
\text { membandingkan berapa banyak } \\
\text { perubahan ranking yang terjadi } \\
\text { jika dibandingkan dengan } \\
\text { kondisi pada saat bobotnya } \\
\text { sama (bobot=1) }\end{array}$ & $\begin{array}{l}\text { Pengujian sensitivitas } \\
\text { metode SAW dan } \\
\text { TOPSIS }\end{array}$ & $\begin{array}{l}\text { Pengujian sensitifitas } \\
\text { bisa dilakukan untuk } \\
\text { membuktikan metode } \\
\text { mana yang jauh lebih } \\
\text { sensitif terhadap } \\
\text { perubahan }\end{array}$ \\
\hline 5 & $\begin{array}{l}\text { Cahyono Sigit Pramudyo dan } \\
\text { Dian Eko Hari Purnomo, } \\
\text { Perancangan Sistem } \\
\text { Pendukung Keputusan Untuk } \\
\text { Pemilihan Pemasok Nata De } \\
\text { Coco Dengan Metode Simple } \\
\text { Additive Weighting }\end{array}$ & $\begin{array}{l}\text { Menentukan kriteria yang berpengaruh } \\
\text { untuk memilih pemasok. }\end{array}$ & $\begin{array}{l}\text { Menentukan kriteria pemilihan } \\
\text { pemasok berdasarkan hasil, } \\
\text { observasi, wawancara dan data } \\
\text { dari perusahaan, dengan proses } \\
\text { metode SAW, Topsis dan WPM }\end{array}$ & $\begin{array}{l}\text { Kriteria-kriteria yang } \\
\text { dapat digunakan untuk } \\
\text { pemilihan pemasok nata } \\
\text { de coco kontrak adalah } \\
\text { jumlah total, jumlah } \\
\text { pengiriman maksimal, } \\
\text { kerutinan, harga, dan } \\
\text { kualitas }\end{array}$ & $\begin{array}{l}\text { Metode SAW dapat } \\
\text { digunakan untuk } \\
\text { menentukan kriteria } \\
\text { pemilihan supplier }\end{array}$ \\
\hline
\end{tabular}

\section{Tinjauan Objek Penelitian}

Proses pemilihan staf peduli laka diawali dengan diterimanya rekomendasi dari koordinator operasi, mekanik dan koordinator kasir yang berhubungan langsung dengan pengemudi yang dinilai layak mendapatkan 
kesempatan untuk memenuhi jabatan sebagai staf peduli laka, penilaian dilakukan dengan melihat absensi operasional dan setoran mitra yang telah dilakukan selama menjadi mitra perusahaan.

Proses selanjutnya yaitu mitra yang menjadi calon akan menjalani wawancara yang akan dilakukan oleh stakeholder perusahaan, dalam hal ini yang menjadi stakeholder antara lain supervisor yang membutuhkan.

\section{Kerangka Pemikiran}

Konsep kerangka pemikiran dapat digambarkan seperti dibawah ini:

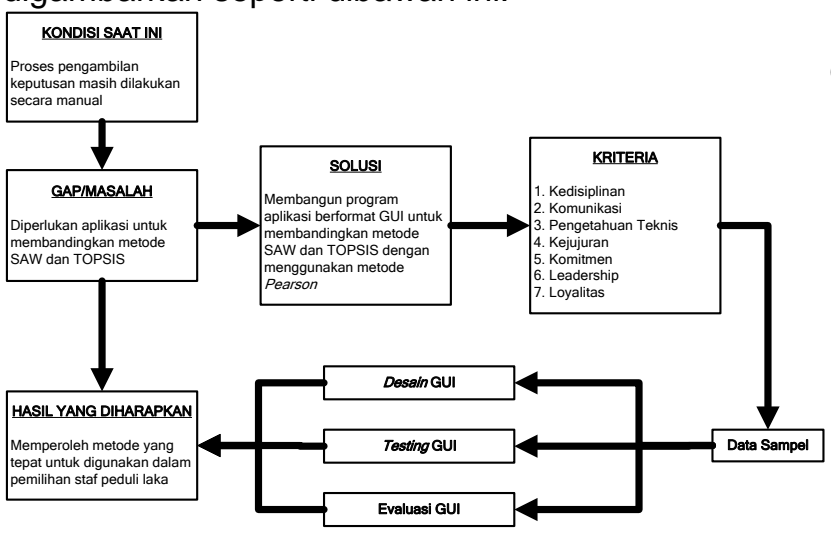

Gambar 1. Kerangka Pemikiran

\section{METODE PENELITIAN}

Penelitian ini bertujuan untuk memutuskan suatu pilihan dari beberapa alternatif berdasarkan suatu kriteria yang telah ditentukan dengan menggunakan pendekatan sistem pendukung keputusan (SPK). Metode pendukung keputusan (SPK) yang digunakan yaitu metode SAW dan metode Technique for Order Preference by Similarity to Ideal Solution (TOPSIS).

Untuk mendapatkan informasi yang diperlukan peneliti melakukan riset di PT Express Pool Cipayung. Kriteria yang diperoleh berdasarkan kebijakan perusahaan. Dalam menganalisa data dengan menggunakan metode SAW dan metode Topsis diperlukan data dari populasi yang disebut data sampel.

Penelitian ini menggunakan teknik pemilihan non random sampel dengan cara Stratified sampling untuk mengambilan sampelnya. Seleksi sampel berdasarkan mitra dan pengemudi yang berstatus bravo yang ada di PT Express Pool Cipayung. Bravo adalah mitra PT Express yang memiliki kepemilikan taksi. Dari data mitra yang ada pada PT Express Pool Cipayung terseleksi sebanyak 12 mitra dan 437 mitra telah dieliminasi dikarenakan absen operasi.
Menurut Kusumadewi (2006:74) "Metode Simple Additive Weighting (SAW) sering juga dikenal istilah metode penjumlahan terbobot. Konsep dasar metode SAW adalah mencari penjumlahan terbobot dari rating kinerja pada setiap alternatif pada semua atribut Metode SAW membutuhkan proses normalisasi matriks keputusan $(X)$ ke suatu skala yang dapat diperbandingkan dengan semua rating alternatif yang ada.

Metode SAW atau yang lebih sering dikenal istilah metode penjumlahan terbobot. Konsep dasar SAW adalah mencari penjumlahan terbobot dari rating kinerja pada setiap altenatif pada semua atribut. Langkah-langkah metode dalam metode SAW adalah (Wibowo, 2008:64):

Langkah-langkah penelitian untuk perancangan SAW:

1. Menentukan variable yang digunakan untuk melakukan diagnosa permasalahan. Variable penelitian yang digunakan dalam penelitian ini berdasarkan kebijakan perusahaan.

Tabel 2. Tabel Variabel

\begin{tabular}{|l|l|}
\hline Fungsi & \multicolumn{1}{|c|}{ Nama Variabel } \\
\hline \multirow{5}{*}{ Input } & Kedisiplinan \\
\cline { 2 - 2 } & Komunikasi \\
\cline { 2 - 2 } & Pengetahuan Teknis \\
\cline { 2 - 2 } & Kejujuran \\
\cline { 2 - 2 } & Komitmen \\
\cline { 2 - 2 } & Leadership \\
\cline { 2 - 2 } & Loyalitas \\
\hline \multirow{4}{*}{ Output } & Metode Yang Memiliki Tingkat \\
& Reliabilitas Tinggi \\
\cline { 2 - 2 } & Seleksi Pengemudi Sebagai \\
& Calon Staf Peduli Laka \\
\hline
\end{tabular}

2. Menentukan nilai nominasi pada setiap alternatif pada setiap kriteria pada matriks keputusan

3. Melakukan defuzzyfikasi matriks dengan merubah nilai awal ke dalam bilangan fuzzy

4. Melakukan normalisasi matriks keputusan

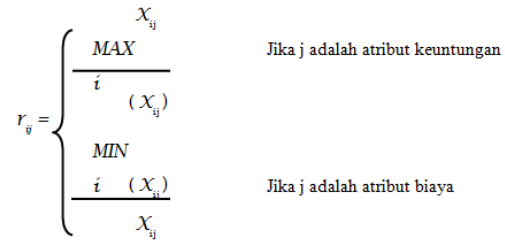

5. Melakukan perkalian atas matriks yang telah dinormalisasi dengan bobot kepentingan yang telah ditetapkan.

6. Melakukan penjumlahan dari setiap kriteria dari masing-masing alternatif dan membuat ranking keputusan.

Technique for Order Preference by Similarity to Ideal Solution (TOPSIS) Menurut Ashtiani (2008) TOPSIS adalah metode beberapa kriteria untuk mengidentifikasi solusi dari satu set alternatif terbatas. Prinsip 
dasarnya adalah bahwa alternatif yang dipilih harus memiliki jarak terpendek dari solusi ideal positif dan jarak terjauh dari solusi ideal negatif. Dalam TOPSIS, rating kinerja dan bobot kriteria tersebut diberikan sebagai nilai crisp."

Langkah-langkah penyelesaian masalah MADM dengan TOPSIS:

1. Menentukan variable yang digunakan untuk melakukan diagnose permasalahan.

2. Membentuk nominasi pada setiap alternatif pada setiap kriteria pada matriks keputusan.

3. Melakukan defuzzyfikasi matriks dengan merubah nilai awal ke dalam bilangan fuzzy.

4. Melakukan normalisasi matriks yang menggunakan rumus perhitungan

$$
\mathrm{r}_{\mathrm{ij}}=\frac{\mathrm{x}_{\mathrm{ij}}}{\sqrt{\sum_{\mathrm{i}=1}^{\mathrm{m}} \mathrm{x}_{\mathrm{ij}}{ }^{2}}}
$$

Dimana $R_{i j}$ adalah hasil dari normalisasi, $X_{i j}$ adalah nilai defuzzyfikasi pada matriks dan $\Sigma x_{i j}{ }^{2}$ adalah jumlah dari nilai defuzzyfikasi yang telah dipangkatkan dua.

5. Mencari solusi positif dan negatif dari setiap kriteria.

$$
\begin{aligned}
& \mathrm{A}+=\left(\mathrm{y}_{1}^{+}, \mathrm{y}_{2}^{+}, \ldots, \mathrm{y}_{\mathrm{n}}{ }^{+}\right) ; \\
& \mathrm{A}-=\left(\mathrm{y}_{1}, \mathrm{y}_{2}, \ldots, \mathrm{y}_{\mathrm{n}}\right) ;
\end{aligned}
$$

6. Membuat alternatif positif dan negatif berdasarkan nilai solusi yang telah didapat baik solusi positif maupun solusi negatif

$$
\begin{aligned}
& \mathrm{D}_{\mathrm{i}}^{+}=\sqrt{\sum_{\mathrm{i}=1}^{m}\left(\mathrm{y}_{\mathrm{i}}^{+}-\mathrm{y}_{\mathrm{i}}\right)^{2}} \\
& \mathrm{D}_{\mathrm{i}}^{-}=\sqrt{\sum_{\mathrm{i}=1}^{\mathrm{m}}\left(\mathrm{y}_{\mathrm{ij}}-\mathrm{y}_{\mathrm{i}}^{-}\right)^{2}}
\end{aligned}
$$

7. Mencari nilai preferensi dari masing-masing alternatif.

$$
\mathrm{V}_{\mathrm{i}}=\frac{\mathrm{D}_{\mathrm{i}}^{-}}{\mathrm{D}_{\mathrm{i}}^{-}+\mathrm{D}_{\mathrm{i}}^{+}}
$$

8. Membuat ranking keputusan berdasarkan urutan hasil preferensi yang didapatkan.

\section{HASIL DAN PEMBASAHAN}

Hasil penelitian meliputi hasil rekapitulasi data kuesioner yang ditujukan pada lampiran dan matriks berpasangan untuk metode SAW dan Technique for Order Preference by Similarity to Ideal Solution (TOPSIS). Sedangkan kriteria yang digunakan dalam pemilihan staf peduli laka ada tujuh kriteria yaitu:

\section{Kedisiplinan}

Maksud dari kriteria kedisiplinan disini adalah ketepatan waktu keluar dan masuk operasi setiap harinya. Apakah mitra yang menjadi calon staf peduli laka disiplin dalam operasi setiap harinya, dan tidak mengurangi atau melewati waktu yang telah diberikan oleh perusahaan untuk beroperasi. Mempunyai nilai yang sangat penting dalam penentuan pemilihan staf peduli laka.

2. Komunikasi

Komunikasi yang baik mitra terhadap staf operasi yang sedang bertugas menjadi tolak ukur untuk menentukan sebaik apa hubungan mitra terhadap staf perusahaan.

\section{Pengetahuan Teknis}

Pengetahuan terhadap peraturan perusahaan maupun peduli laka yang baik adalah nilai plus untuk calon staf peduli laka untuk menjadi yang terpilih

4. Kejujuran dalam Operasi

Kejujuran mitra dalam operasi diukur dari jumlah pendapatan dan jumlah yang disetorkan kepada kasir apakah memiliki selisih yang tidak sesuai dengan yang dilaporkan.

\section{Komitmen}

Komitmen ini lebih kepada jumlah total setoran yang seharusnya di setorkan dengan jumlah setor yang telah dibayarkan apakah sudah memenuhi sesuai perjanjian mitra dengan perusahaan.

\section{Leadership}

Kemampuan dalam memimpin ini dinilai dari wawancara yang dilakukan terhadap mitra yang menjadi calon staf peduli laka juga sesuai dengan pengetahuan pimpinan terhadap calon staf peduli laka itu sendiri.

\section{Loyalitas}

Setiap mitra memiliki hak untuk tidak beroperasi pada hari libur yang telah ditentukan oleh perusahaan namun jadi nilai lebih untuk mitra yang tetap beroperasi walaupun pada hari libur mitra.

\section{Simple Additive Weighting (SAW)}

a) Memberikan nilai bobot preferensi (W) oleh pengambil keputusan untuk masing-masing kriteria yang sudah ditentukan. setiap kriteria memiliki nilai bobot kepentingan masing-masing dan nilai bobot ini telah diubah menjadi nilai bilangan fuzzy.

b) Membuat Nominasi Matriks keputusan, dimana Nama Calon adalah alternatif yang akan dipilih dan Kriteria adalah kriteria. Nilai yang diisi pada nominasi matriks ini didapatkan dari nilai hasil wawancara calon atau alternatif. 
Tabel 3. Nominasi Matriks

\begin{tabular}{|c|c|c|c|c|c|c|c|}
\hline \multirow{2}{*}{ ALTERNATIF } & \multicolumn{7}{|c|}{ KRITERIA } \\
\cline { 2 - 8 } & C01 & C02 & C03 & C04 & C05 & C06 & C07 \\
\hline A01 & 4 & 3 & 3 & 2 & 3 & 2 & 2 \\
\hline A02 & 4 & 2 & 4 & 3 & 2 & 2 & 4 \\
\hline A03 & 5 & 5 & 4 & 5 & 5 & 5 & 5 \\
\hline A04 & 5 & 3 & 4 & 2 & 3 & 2 & 1 \\
\hline A05 & 4 & 2 & 2 & 3 & 2 & 2 & 2 \\
\hline A06 & 4 & 2 & 3 & 3 & 4 & 3 & 3 \\
\hline A07 & 5 & 3 & 3 & 4 & 3 & 3 & 2 \\
\hline A08 & 4 & 4 & 4 & 4 & 4 & 4 & 3 \\
\hline A09 & 5 & 3 & 3 & 2 & 4 & 3 & 3 \\
\hline A10 & 4 & 3 & 4 & 3 & 3 & 4 & 3 \\
\hline A11 & 5 & 4 & 4 & 3 & 4 & 2 & 4 \\
\hline A12 & 5 & 4 & 5 & 4 & 4 & 5 & 3 \\
\hline
\end{tabular}

c) Merubah nilai nominasi kedalam bilangan fuzzy yang telah ditetapkan yang disebut dengan defuzzyfikasi.

Tabel 4. Pengukuran Parameter

\begin{tabular}{|l|c|c|}
\hline Parameter & Score & $\begin{array}{c}\text { Nilai } \\
\text { Fuzzy }\end{array}$ \\
\hline Sangat Baik & 5 & 1 \\
\hline Baik & 4 & 0,8 \\
\hline Cukup Baik & 3 & 0,6 \\
\hline Kurang Baik & 2 & 0,4 \\
\hline Tidak Baik & 1 & 0,2 \\
\hline
\end{tabular}

d) Melakukan normalisasi matriks keputusan dengan cara menghitung nilai rating kinerja ternormalisasi (rij) dari alternatif Ai pada atribut $\mathrm{Cj}$.

Dengan rumus:

$\mathrm{R}_{11}=\mathrm{A} 1 \mathrm{C} 1 / \mathrm{Max}(\Sigma \mathrm{C} 1)$

$R_{11}=0,8 / 1,0$

$R_{11}=0,8$

e) Mencari hasil dari nilai rating kinerja ternormalisasi $\left(r_{i j}\right)$ membentuk matriks ternormalisasi $(\mathrm{N})$ lalu di proses berdasarkan bobot kriteria masingmasing

f) Melakukan proses perankingan dengan cara menjumlahkan nilai hasil dari pembobotan.

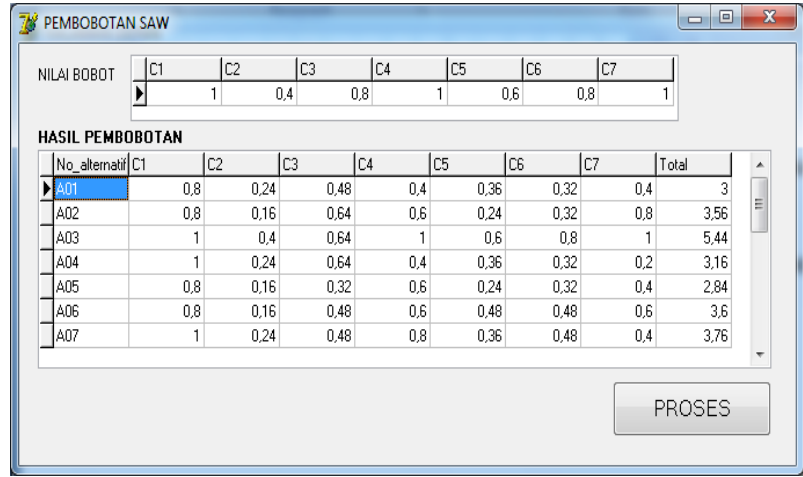

Gambar 2. Implementasi Metode SAW

2. Technique for Order Preference by Similarity to Ideal Solution (TOPSIS)

a) Membuat sebuah nominasi matriks Keputusan. Nominasi ini sama dengan nominasi yang diberikan pada metode SAW

b) Merubah nilai nominasi kedalam bilangan fuzzy yang telah ditetapkan yang disebut dengan defuzzyfikasi. Langkah ini juga sama dengan proses defuzzyfikasi pada metode SAW

c) Melakukan normalisasi matriks dengan rumus nilai matriks defuzzyfikasi dipangkatkan dua lalu di jumlahkan pada setiap kriteria dan selanjutkan nilai hasil pangkat dibagi dengan jumlah dari nilai hasil pangkat pada setiap kriteria Dengan rumus:

$R_{i j}=X_{i j} / \sqrt{ } \sum x_{i j}^{2}$

$R_{i j}=0,8 / \sqrt{ } 9,84$

$\mathrm{R}_{\mathrm{ij}}=0,255$

d) Setelah matriks dibuatkan normalisasinya, selanjutnya dilakukan pembobotan dimana nilai hasil normalisasi dikalikan dengan nilai bobot yang sudah diubah menjadi bilangan

e) Setelah melakukan pembobotan matriks, selanjutnya dicari solusi positif dari setiap kriteria dengan melakukan perhitungan dimana nilai solusi positif adalah nilai maksimal dari setiap alternatif pada kriteria

Dengan rumus:

$\mathrm{A}+=\operatorname{Max}(\mathrm{Ai})$

$A+=0,3188$

sedangkan untuk solusi negatif dengan melakukan perhitungan dimana nilai solusi negatif didapatkan dari nilai minimal pada setiap alternatif pada kriteria

Dengan rumus:

$\mathrm{A}-=\operatorname{Min}(\mathrm{Ai})$

$A-=0,255$

f) Setelah didapat nilai dari solusi positif dan negatif maka selanjutnya dicari nilai dari alternatif masing-masing solusi. 
Untuk mencari nilai alternatif positif dimana solusi positif dikalikan dengan nilai hasil normalisasi.

Dengan rumus:

$D_{i+}=\sqrt{ } \sum(A+-A i j)$

$D_{i}-=\sqrt{ } \sum($ Aij $-A-)$

Dan hasil dari alternatif positif pada

Calon 1 hingga 12 adalah $(0,2274)$, $(0,2497),(0,0270),(0,0901),(0,1922)$, $(0,1079),(0,2333),(0,2248),(0,3249)$, $(0,0901),(0,1878),(0,2014)$,

Sedangkan untuk hasil dari alternatif positif pada Calon 1 hingga 12 adalah $(0,1495),(0,0968),(0,2958),(0,2239)$, $(0,1323),(0,1692),(0,1317),(0,1455)$, $(0,0173),(0,2239),(0,1468),(0,0585)$

g) Jika semua alternatif sudah mendapatkan nilai alternatif positif dan negatifnya maka selanjutnya dilakukan pencarian nilai preferensi untuk masingmasing alternatif dimana nilai hasil alternatif negatif dibagi dengan hasil alternatif negatif yang telah ditambah dengan hasil alternatif positif.

Dengan rumus:

$V_{i}=D_{i}^{-} / D_{i}^{-}+D_{i}^{+}$

$V_{i}=0,1495 / 0,1495+0,2274$

$V_{i}=0,0671$

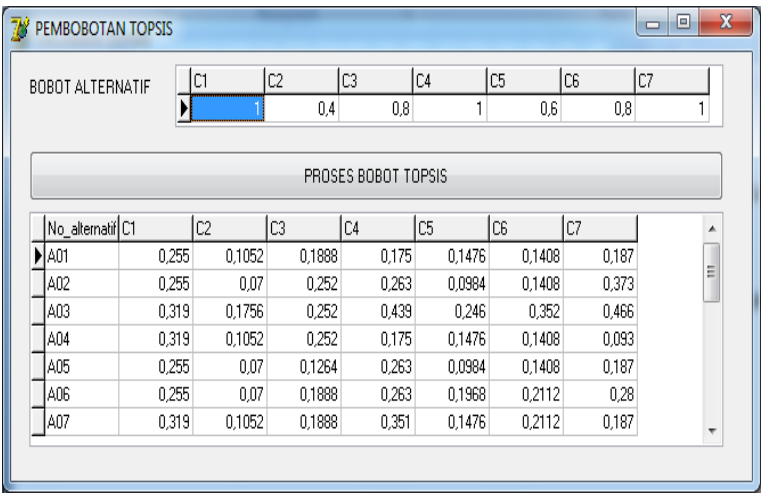

Gambar 3. Implementasi Metode Topsis

\section{Hasil Metode SAW dan TOPSIS}

Tabel 5. Hasil Metode SAW dan TOPSIS

\begin{tabular}{|l|c|c|c|c|}
\hline \multirow{2}{*}{\multicolumn{1}{|c|}{ ALTERNATIF }} & \multicolumn{2}{c|}{ SAW } & \multicolumn{2}{c|}{ TOPSIS } \\
\cline { 2 - 5 } & SCORE & RANKING & SCORE & RANKING \\
\hline A01 = ABDUL RAJAB & 3 & 11 & 0,067 & 12 \\
\hline A02 = AGUS SUBHAN & 3,56 & 9 & 0,449 & 6 \\
\hline A03 = EMEN BIN USIN & 5,44 & 1 & 0,987 & 1 \\
\hline A04 = FATCHUR RIZAQ & 3,16 & 10 & 0,080 & 10 \\
\hline A05 = HARDIANTO GAJAH & 2,84 & 12 & 0,068 & 11 \\
\hline A06 = KARNAWI & 3,6 & 8 & 0,339 & 7 \\
\hline A07 = MARWIN & 3,76 & 6 & 0,292 & 8 \\
\hline A08 = MILTEN SIAGIAN & 4,28 & 3 & 0,662 & 3 \\
\hline A09 = NURZAMAL PUTRA & 3,68 & 7 & 0,285 & 9 \\
\hline A10 = SIDI BIN KANUNG & 3,88 & 5 & 0,468 & 5 \\
\hline A11 = SUGIN0 & 4,16 & 4 & 0,568 & 4 \\
\hline A12 = SURYADI & 4,8 & 2 & 0,781 & 2 \\
\hline
\end{tabular}

Dilihat dari hasil pada Tabel 5 dalam metode SAW dan TOPSIS A03 yaitu alternatif 03 menduduki urutan pertama.

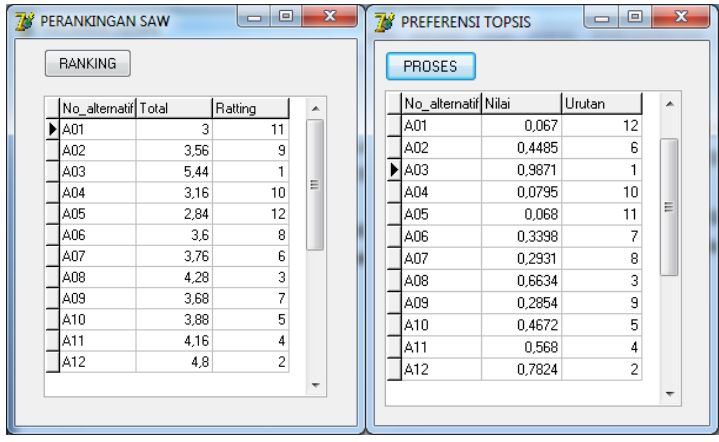

Gambar 4. Hasil dari Metode SAW dan Topsis

\section{E. KESIMPULAN DAN SARAN}

Berdasarkan hasil penelitian dan pembahasan maka penyelesaian untuk pokok permasalahan yang telah dirumuskan dapat disampaikan kesimpulannya, yaitu :

Metode Topsis dinilai lebih relevan dalam menghasilkan sebuah keputusan dibandingkan dengan metode SAW dikarenakan setelah dilakukan pengujian dengan metode Pearson untuk reliabilitas tertinggi ada pada metode Topsis sebesar 0,9770 sedangkan metode SAW sebesar 0,9564.

Dari penelitian ini, peneliti menyadari ketidaksempurnaan dari penelitian ini. Maka diperlukan beberapa saran yang dapat meningkatkan penelitian ini, yaitu :

1. Variabel dan indikator serta metode penilaian yang lain perlu diterapkan untuk menambahkan kehandalan sistem diwaktu yang akan datang.

2. Dilakukan pengujian lain terhadap hasil dari metode penunjang yang lain khususnya yang datanya berupa data kuantitatif agar dapat membuktikan kualitas dari hasil metodenya. 
3. Lakukan penelitian kolaborasi antara beberapa metode MADM.

\section{DAFTAR PUSTAKA}

[1] Ashtiani, B., Haghighirad, F., Makui, A., Montazer, G.A., 2008. Extension of Fuzzy TOPSIS Method Based on Interval-valued Fuzzy Sets. Applied Soft Computing. Vol. 9, No.2, 457-461

[2] Kadir, Abdul, Terra Ch.Triwahyuni. 2003. Pengenalan Teknologi Informasi. Yogyakarta: Andi Offset.

[3] Kusrini. 2009. Konsep dan Aplikasi Sistem Pendukung Keputusan. Yogyakarta : Andi Offset.

[4] Kusumadewi, Sri. 2006. Fuzzy MultiAttribute Decision Making (Fuzzy MADM). Yogyakarta : Graha Ilmu.

[5] Kusumadewi, Sri. 2007. Diktat Kuliah Kecerdasan Buatan, Jurusan Teknik Informatika, Fakultas Teknologi Industri, Universitas Islam Indonesia.

[6] Wibowo. 2008. Sistem Pendukung Keputusan Untuk Menentukan Penerima Beasiswa Bank BRI Menggunakan MADM (Studi Kasus: Mahasiswa Fakultas Teknologi Industri Unversitas Islam Indonesia). Yogyakarta: Prosiding Seminar Nasional Aplikasi Teknologi Informasi. Halaman $62-67$. 